Original Research Paper

\title{
Beef Productivity of Limousine Cattle at Stable Keeping
}

\author{
${ }^{1}$ Irina Vlasova, ${ }^{1}$ Inna Ventsova, ${ }^{1}$ Alexander Vostroilov, ${ }^{1}$ Vladimir Safonov and ${ }^{2}$ Andrey Golubtsov \\ ${ }^{1}$ Department of Private Animal Husbandry, \\ Voronezh State Agrarian University named after Emperor Peter the Great, Voronezh, Russian Federation \\ ${ }^{2}$ Department of Veterinary and Sanitary Examination, Epizootology and Parasitology, \\ Voronezh State Agrarian University named after Emperor Peter the Great, Voronezh, Russian Federation
}

\author{
Article history \\ Received: 21-08-2020 \\ Revised: 22-10-2020 \\ Accepted: 23-10-2020 \\ Corresponding Author: \\ Inna Ventsova \\ Department of Private Animal \\ Husbandry, Voronezh State \\ Agrarian University named \\ after Emperor Peter the Great, \\ Voronezh, Russian Federation \\ Email: ventsovair668@rambler.ru
}

\begin{abstract}
The regularities of the post-embryonic development of farm animals have been studied by numerous researchers. Their ontogenesis is a result of the complex interaction of animal genotype with those conditions of the external environment in which their hereditary basis is realized. In Russia, the stable keeping system of the cattle is highly relevant as many farms do not have large areas allocated for natural pastures. Therefore, a task has been set to study the growth, development and beef productivity of Limousine cattle in the age aspect under stabling conditions, namely, bulls from the birth to meat production and heifers from birth to first-calf heifers. The object of research was purebred bulls and heifers of Limousine breed, which are grown on the territory of the Central Chernozem area of the Russian Federation. It has been established that intensive use of Limousine cattle contributes to the rapid increase of high-quality beef. The performed studies showed that Limousine bulls and heifers demonstrate essential differences in growth intensity. In main age periods, bulls outnumbered heifers by $160.2 \mathrm{~kg}$ in live weight and 451.6 grams in average daily growth and also proved to be more stress-resistant to changes in external conditions. When estimating beef productivity, limousine bulls are characterized by a rather high live weight of $688.7 \mathrm{~kg}$. The slaughter yield of 20 monthly bulls was $63.2 \%$.
\end{abstract}

Keywords: Beef Productivity, Breeding, Cattle, Limousine Cattle, Livestock

\section{Introduction}

The formation of a specialized industry of beef cattle breeding in the world began in the 18th century, when such classical breeds as Aberdeen-Angus, Shorthorn, Hereford and others were created. The distinctive feature of beef farming is that the production process is divided into several stages, which distinguishes it from other specialized areas of livestock breeding. All stages can be performed in one household or on one farm. Often, one or more stages of the process is carried out on different farms and even in different agricultural areas. That is, beef cattle can be bred both on farms with a closed cycle and with a pronounced specialization and concentration of production, which in each case should be justified by economic efficiency (Phocas and Laloë, 2004).

Modern achievements in agricultural science provide livestock scientists and practitioners with a wide range of opportunities to increase livestock productivity and improve the quality of products and raw materials. Many of these techniques offer the possibility to increase the efficiency of beef cattle breeding in a short period with minimal costs. However, their implementation into production contributes only to a better realization of the breeding potential and does not directly affect the entire genetic complex of the animal. Such an approach will inevitably lead to reaching a limit of hereditary criteria of productivity, beyond which its further increase will be impossible. Considering such experience, the enterprises of the Russian Federation take active measures for the use of highly productive specialized beef breeds of cattle, while improving feeding and housing systems, as well as forms of production arrangement and technological cycles (Gangnat et al., 2016).

At present, several foreign breeds from the European Union are also adopted along with the beef cattle breeds used in Russia. One of these breeds is Limousine, which has adapted quite well to the Russian conditions. 
However, in Russia, the number of Limousine cattle comprises only $1.8 \%$ of the total livestock in the country. Animals of this breed have high growth intensity, low fat content in the carcass, a higher output of muscle tissue, excellent meat quality and can build up muscle tissue for a long period without intensive fat deposition. They adapt well to different weather conditions and quickly acclimate. Limousines are unpretentious, hardy and have good fertility. Therefore, animals of this breed are most effectively used in beef cattle breeding (Avzalov, 2016).

Many farms in Russia do not have large areas dedicated to uncultivated pastures. In this regard, the stable housing system becomes quite relevant. Besides, a specific feature of this keeping type is reduced energy consumption required for the work of muscles during transferring from one pasture to another, as well as in the movement of the animal on the pasture itself. At that, the usual daily rhythm of an animal's life does not change. The loss of live weight is also minimized when changing the diet from winter to summer and vice versa, as with this housing system, the feeding is carried out by complete feed mixtures. Thus, the purpose of the research was to analyze the growth and beef productivity of Limousine cattle breeds in the conditions of the Central Chernozem area of the Russian Federation. The task of the research was to analyze the specifics of growing Limousine bulls and heifers by periods of development in the conditions of stable keeping system, as well as to estimate beef productivity by results of control slaughter, which reflects the novelty of the study performed.

\section{Literature Review}

Beef cattle have particular advantages, such as endurance and unpretentiousness to living conditions, as well as good adaptability to different environmental conditions. This ability has been developed in them because the animals have been exposed to adverse feeding and housing conditions for a long time. Their bodies have developed adaptive abilities such as the accumulation of vital nutrients under favorable conditions and their efficient use during the winter periods before the pasture season. Beef cattle also consolidate subcutaneous fat deposits by the beginning of winter periods in order to survive adverse weather conditions associated with frosts and winds (Dick et al., 2015).

The number of beef cattle livestock is increasing every year. According to the data of Beef Breeds Associations, in the USA, for example, the number of livestock population increased from 30 to 40 million within the period from 1940 to 2000 and carcass weight at slaughter, as well as protein production, more than doubled (Cunningham and Klei, 1995; Lukianov, 2017).
By the nature of livestock farming and sources of beef production, the countries of the world are divided into three groups. The first group includes most European countries, where cattle are mainly bred for milk and beef is produced as a co-product. The second group includes countries with developed dairy and specialized beef cattle breeding such as Great Britain, Italy and France. The third group comprises Argentina, Uruguay, the USA, Canada and Mexico, where beef cattle husbandry has developed (De Vries et al., 2015).

In Western European countries with a high population density and high land value, livestock production is intensively developed with high labor and resource costs. Cattle is represented by up to $80 \%$ of dairy and beef breeds. The exceptions are England and France, where beef cattle breeding is both commercial and broad-breeding (Ambrosini et al., 2016).

Beef cattle husbandry is most developed in the USA, Canada, England, Australia and South America, where it outnumbers dairy cattle by livestock population and produces from 70 to $90 \%$ of beef. A characteristic feature of the countries mentioned is the large areas dedicated to natural pastures.

Natural land is used with artificial pastures through arable land sown with annual and perennial grasses, as well as grain crops. At that, the amount of livestock on pastures in different regions varies and depends on natural conditions, the degree of pasture availability and the direction of livestock breeding development. Intensification of fodder cropping includes both production of forage for stable winter keeping and summer keeping of livestock, creation of hayfields and pastures in crop rotations and improvement of natural lands (Albertí et al., 2008; Crichton et al., 2017; Vorobyev et al., 2019).

The intensification of beef cattle breeding on industrial farms of the Russian Federation is provided through the use of a stable housing system. The industrial livestock breeding complex is a large specialized enterprise, the principal and auxiliary facilities of which are connected with each other by a single production technology that provides high quality products with minimal labor and material costs rhythmically during the year. In this case, the Bolshevik LLC farm belongs to such a livestock breeding complex. Thus, some researchers consider expedient to grow young animals at a continuously high level of feeding before the realization on meat, bypassing stages of the nursery and fattening. Such technology allows reaching young beef breeds with a live-weight of 500-600 kg in 15-18 months (Nogalski et al., 2016).

\section{Problem Statement}

Enterprises with animal pasture are not common for Russia. A significant number of farms keep cattle in 
cowsheds without tethers and grazing because natural conditions in many regions are not favorable for keeping cattle on pasture. Also, lack of forage base prevents such projects from further development. On large complex farms with modern technologies, pasture keeping of cattle is not exercised as it is necessary to provide certain conditions of maintenance and care of the grassland for this purpose.

The climate in Russia is excellent for cattle and, in terms of pasture productivity, Vologda Region is better than New Zealand, for example. Animals in this country live outdoors all year round: In summer (from September to May) they eat grass, in winter they are fed with hay. World experience shows that only in some countries, such as Ireland, New Zealand and Australia, climatic and natural conditions allow keeping cattle on pastures most of the year. In the European part of Russia, the pasture period lasts 3-3.5 months, while in the eastern part, it is even less. Although in the southern and south-eastern regions it can last up to six months with limited potential for grazing. Partial use of pastures in summer and keeping of cattle in cowsheds in winter is also poorly relevant in most regions.

The development of beef cattle breeding in Russia is determined by progressive technology, including primarily the use of specialized beef breeds adapted to natural conditions. The second important element is the reproduction and cultivation of suckler calves and the third one is the growth of young calves after ablactating and getting a sufficient number of remount heifers and the last one is the arrangement of intensive fattening. These elements constitute a single production process that ensures the use of the genetic potential of beef animals and the economic efficiency of the industry.

Based on this, the purpose of this research was to analyze the formation of cattle beef productivity in the age aspect in Limousines at stable keeping conditions in the Central Chernozem area of the Russian Federation.

The research tasks included the analysis of the growth peculiarities of Limousine bulls and heifers by periods of development in the conditions of the stable housing, as well as estimate beef productivity by results of control slaughter, which reflects the novelty of the work performed.

\section{Date Analysis}

Statistical data processing was performed in the IBM SPSS Statistics 20.0 program applying the Student's t-criterion.

\section{Materials and Methods}

The research was performed on animals of the Bolshevik LLC farm of Khokholsky District, Voronezh Oblast, geographic coordinates: 51.456343, 38.704219.
The first livestock of Limousine heifers was brought to Bolshevik LLC from Belgorod Semena LLC of Shebekinsky district in the Belgorod region. In June 2011, another 12 heads of livestock were brought. For 5 years, the total number of cattle grew up to 52 due to own reproduction. In the next 5 years, the farm is planning to continue increasing the number of Limousine cattle.

In this regard, the zootechnical service of the farm was assigned the task to evaluate the available livestock by tribal and productive qualities and to develop a plan of tribal work with the herd for 2020-2023.

All breeding stock of the farm was inseminated by Flirt 69, a purebred bull of Limousine breed. Thus, the increase in the number of beef cattle is due to the purebred cultivation of animals.

As of the beginning of 2019, 208 heads of purebred Limousine cattle, including 71 heads of cows, 1 servicing bull, 46 springer heifers and heifers older than two years and 9 bulls aged 10-18 months, have been rated.

The class of the breeding livestock is high. From 71 cows, only 2 are classified as elite, all other classes are elite-record. Among 466 heifers older than two years, only 3 are classified as elite and 43 are classified as elite- record cattle.

The class of the servicing male livestock population is also high. According to estimation results, 10 heads of bulls, including 1 servicing bull, were rated as elite-record class.

Bulls for service working in the herd are characterized by a high live-weight amounting to $980 \mathrm{~kg}$ at the age of 5 years.

Remount young animals are also characterized by high live weight. Thus, the average weight of 16 calves at 205 days after weaning was $222 \mathrm{~kg}$, that of 35 heifers - 213 and at 88 months of age, the weight was 537 and $475 \mathrm{~kg}$, respectively.

For scientific and economic experience, twenty pairs of purebred bulls and heifers of Limousine breed were selected. To study the beef productivity, these animals were assigned in groups by a method of selecting pairsanalogs considering age and live weight.

The experiment was conducted in the Russian Federation and beef productivity was assessed following the interstate standard GOST 34120-2017 "Cattle for slaughter. Beef and veal carcasses, semi-carcasses and quarters", which was introduced as a national standard in the Russian Federation from January 1 $1^{\text {st }}, 2019$ by the Interstate Council for Standardization, Metrology and Certification (Gorbatov, 2017).

Before slaughtering, young cattle were assessed by categories. Results of mass slaughter of Limousine bulls at 20 months of age are presented in (Table 1). 


\section{Results}

It has been established that bulls and heifers showed significant differences in growth intensity at different age periods (Fig. 1). At the same time, heifers have a higher live weight compared to bulls at 1 to 3 months of life, i.e., $50.70 \pm 1.66<56.40 \pm 1.66,77.75 \pm 1.48<$ $81.05 \pm 1.38$ and $102.15 \pm 2.12<103.20 \pm 2.30$, respectively. Then, from 6 months onwards, body mass gain increases in favor of bulls $(197.35 \pm 2.24>185.65 \pm 3.06)$ $(\mathrm{p}<0.001)$. It is especially noticeable from the 8th month of life $(263.55 \pm 3.24>247.15 \pm 2.51)(\mathrm{p}<0.05)$, as the heifers did not gain weight as intensively from this period. Obviously, it can be attributed to the stress experienced after ablactating. The bulls were more stressresistant and weaned more calmly and already from 10 months, they demonstarted active weight gain $(315.65 \pm 2.85$ $>284.10 \pm 2.14)(\mathrm{P}<0.001)$. In the period from 13 to 15 months, a decrease in body weight gain of heifers was recorded $(427.15 \pm 6.87>349.95 \pm 2.15,464.90 \pm 8.41>$ $371.85 \pm 2.45$ and $500.50 \pm 8.86>392.90 \pm 2.66(\mathrm{P}<$ $0.001)$, respectively. Probably, this is because the genetically determined growth rate of heifers associated with the onset of physiological maturity for further reproduction is lower than that of bulls. As a result, by the age of 19 months, bulls retained the advantage in live weight and reliably outperformed heifers by $160.2 \mathrm{~kg}$ $(619.20 \pm 8.98>459.00 \pm 2.18)(\mathrm{P}<0.001)$.
A more detailed understanding of the animal's growth intensity can be obtained from the average daily growth data (Fig. 2).

From the data presented in Fig. 2 follows that the average daily growth over the growing period varies due to different growth rates of young livestock at different age periods. Although the daily average growth rate of heifers has increased, it was less intensive. Thus, analysis of daily growth data of the experimental livestock population testifies that bulls showed higher growth intensity with age in comparison with heifers due to different reaction of the animal organism to changes in external conditions in different periods of ontogenesis.

Average daily weight gain is an important indicator of the animal's growth intensity, but it cannot fully characterize the actual growth rate of young animals over a long period. This is because only the initial body weight gain is taken into account. In this regard, completer and more objective understanding of the animal's growth intensity give the index of relative growth rate, which is calculated not with regard to the initial body weight but to the average live weight for this or that period and also the increase of the live weight factor with age. The relative growth rate reaches the maximum level in its earliest phase and decreases with age (Fig. 3).

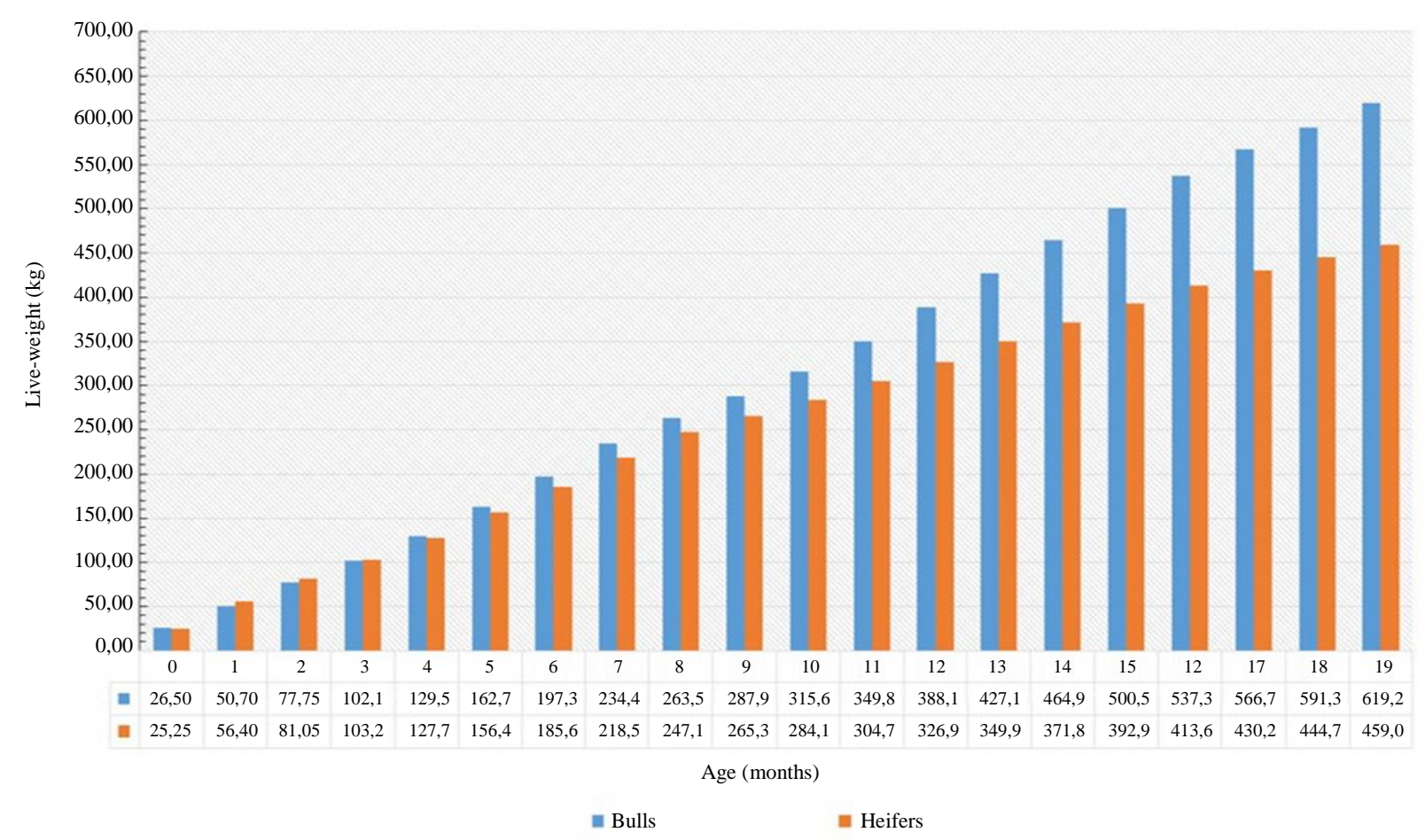

Fig. 1: Live weight dynamics of experimental animals, $\mathrm{kg}(\mathrm{n}=20)$ 


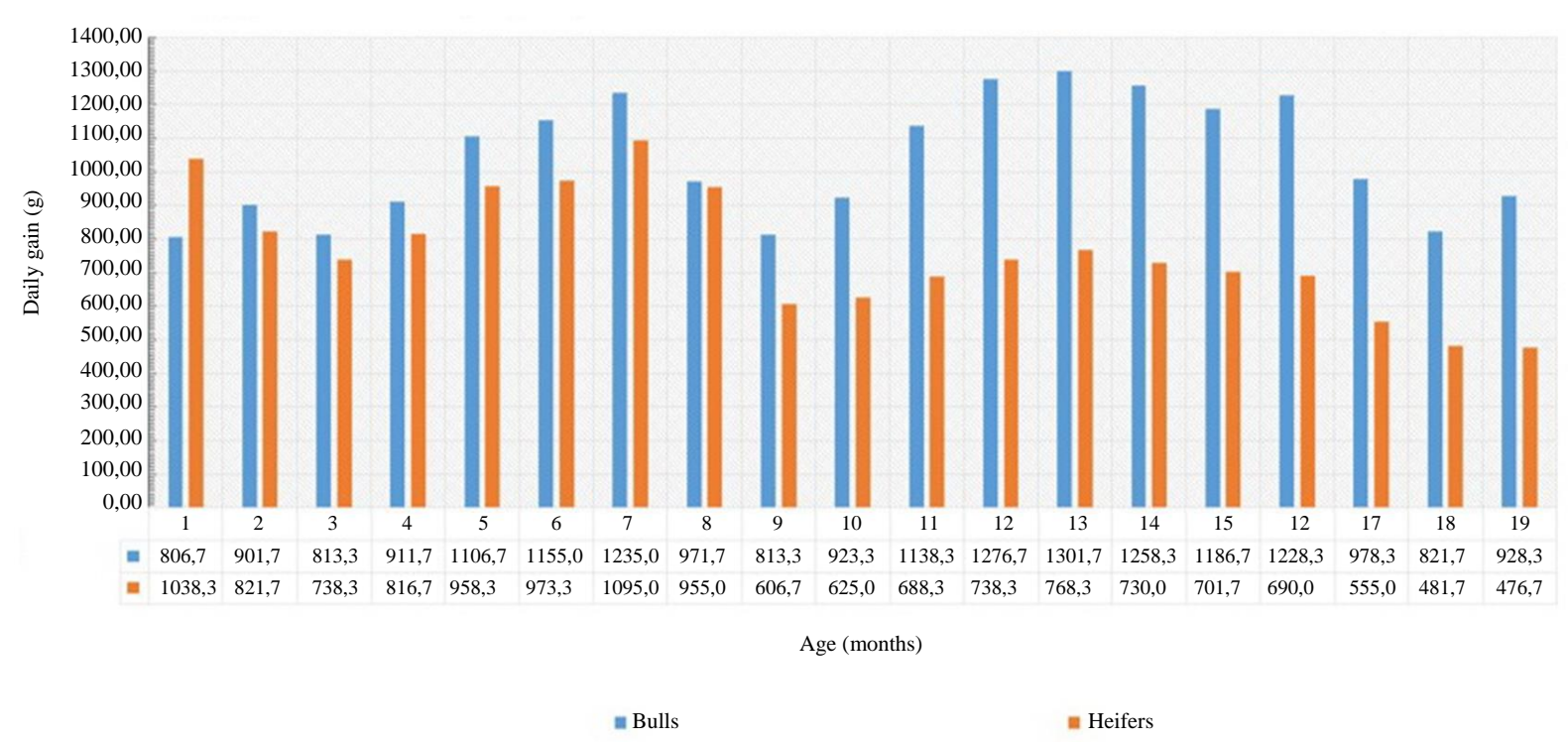

Fig. 2: Average daily growth dynamics of the experimental population, $g(n=20)$

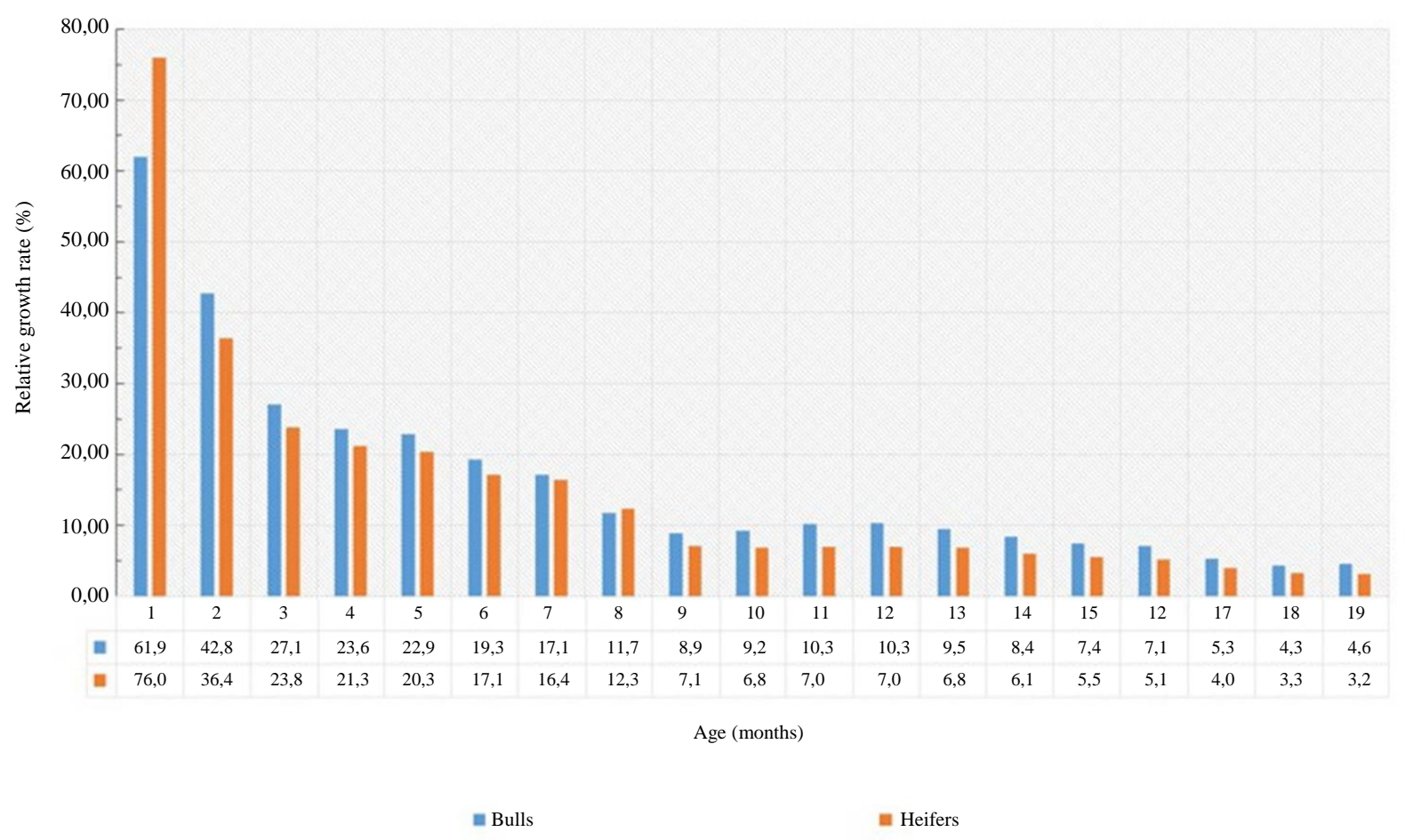

Fig. 3: Dynamics of the relative growth rate of the experimental livestock population, $\%(n=20)$

Analysis of the data in Fig. 3 shows that the relative growth rate of animals decreased with age. The maximum growth rate increase was registered in the first month of life in heifers $-76 \%$, which is $14.1 \%$ more than in bulls $(61.9 \pm 2.7<76.0 \pm 1.7)$. By the age of 3 months, no significant differences between bulls and heifers were found. The difference was $3.3 \%(27.1 \pm 0.9>23.8 \pm 1.4)$ in favor of bulls. The relative growth rates of experimental animals at the age of 8 months were equally low $11.7 \pm 0.5<12.3 \pm 0.7$, which is consistent with the data obtained on average daily growth. In general, the decline in growth rate continued and its minimum indicators reached $4.3 \%(4.3 \pm 0.2)$ for bulls at 18 months and $3.2 \%$ $(3.2 \pm 0.2)$ for heifers at 19 months. Thus, the indicators of relative growth rate depended on the intensity of live weight gain in certain age periods. 
Table 1: Results of mass slaughter of Limousine bulls at 20 months of age

\begin{tabular}{lllr} 
& & Bulls $(\mathrm{n}=19)$ & $\mathrm{S}, \%$ \\
\hline Indicators & & $\mathrm{M} \pm \mathrm{m}$ & 6.9 \\
\hline Live weight at the end of growing period, & $\mathrm{kg}$ & $688.7 \pm 11.0$ & 6.6 \\
Live weight at entry to the meat processing plant, & $\mathrm{kg}$ & $674.0 \pm 10.2$ & 6.7 \\
Empty slaughter live weight, & $\mathrm{kg}$ & $646.0 \pm 10.0$ & 41.6 \\
Loss of live weight during transportation & $\mathrm{kg}$ & $14.6 \pm 1.4$ & 37.4 \\
& $\%$ & $2.1 \pm 0.2$ & 21.0 \\
Live weight loss after 24 h of starvation & $\mathrm{kg}$ & $28.0 \pm 1.3$ & 20.8 \\
& $\%$ & $4.3 \pm 0.2$ & 17.7 \\
Total loss of live weight & $\mathrm{kg}$ & $42.6 \pm 1.7$ & 14.9 \\
& $\%$ & $6.2 \pm 0.2$ & 24.0 \\
Slaughter weight, & $\mathrm{kg}$ & $408.9 \pm 21.5$ & 20.3 \\
Slaughter yield, & $\%$ & $63.2 \pm 2.8$ & \\
\hline
\end{tabular}

Beef productivity indicators and quality of slaughter products depend on the intensity of growing (feeding and keeping) of young animals, age, sex, live weight, breed, as well as transportation conditions, pre-breeding and some other factors.

Housing and feeding conditions for the bulls were similar. The diets used to feed the bulls were fully balanced and matched the animals' needs for all nutrients, micronutrients and macronutrients, ensuring good average daily weights through intensive growth and development of young animals.

The control slaughter of bulls was made when they reached the age of 20 months (Table 1).

The main indicator of beef productivity is the weight of the carcass. The highest carcass mass is formed in well-developed animals with strong skeleton and externally distinguishable excellent execution of muscle tissue. The heavier the carcass is obtained at minimum feed, labor and cost consumption, the higher the efficiency of growing such animals.

The analysis of the presented data confirms that within the limits of the age, bulls of Limousine breed have quite high live weight $(688.7 \pm 11.0 \mathrm{~kg})$. The live weight at the entry to the meat processing plant was 674 $\mathrm{kg}$. The loss of live weight during transportation was $14.6 \mathrm{~kg}$ or $2.1 \%$. Live weight loss after $24 \mathrm{~h}$ of starvation was $28.0 \mathrm{~kg}$ or $4.3 \%$. The total loss of live weight in absolute and relative terms was $42.6 \mathrm{~kg}$ or $6.2 \%$. The slaughter weight was $408.9 \mathrm{~kg}$. It was established that the slaughter yield in 20 monthly bulls was high - 63.2\% (63.2 \pm 2.8$)$ due to the more powerful development of muscle tissue in their carcasses, which is attributed to the high genetic potential of these animals acquired in the process of long-term selection. The data obtained are one of the arguments proving the expediency of growing bulls for up to 20 months.

\section{Discussion}

Most farms in Russia adhere to the stable housing system, although the country has huge pasture resources, which are suitable for grazing and fodder cropping. Besides, the quality of grass in the country is even higher than in countries with a more favorable climate (New Zealand, Greece, Turkey) but only two-thirds of natural areas are used in many regions. Another problem related to the grazing of cattle is the high level of arable land and the lack of natural and cultural pastures, in particular in the Central Chernozem zone. In this regard, the central region uses a stable system for the keeping of cattle.

Pastoralism is indeed more developed in some regions. Thus, in the southern regions, pastures are sometimes even overloaded due to developed sheep breeding, but in such regions as Siberia and the Far East, pastures and arable lands are mostly considered abandoned. The neglect of pastures has been influenced by the fact that meat entrepreneurs have focused on creating large livestock complexes. For them, to keep cattle in stalls is more economically expedient than to graze on pastures (Batanov and Starostina, 2017).

At the current stage of development of agriculture, one of the important problems facing the agro-industrial complex is the increase in the production of meat and, first of all, beef, which is the most acceptable for the normal life activity of the human body due to its biological qualities. In this connection, the efficiency of animal breeding development depends on the productivity of farm animals. Also, the understanding of biological patterns of animal growth and development is of great importance not only in terms of theory but also for modern animal breeding, because the breeding qualities and productivity of farm animals are inextricably linked with the age characteristics of each animal (Abbasov and Abdulaeva, 2015).

The process of increasing the mass of cells in the body, its organs and tissues, the linear and volumetric sizes at the expense of quantitative changes of a living substance and the individual development of an animal, or its ontogenesis, is understood as a set of quantitative and qualitative changes occurring with age in cells, tissues and in the whole organism under the influence of 
heredity of a given individual and its constant interaction with the environment (Bragaglio et al., 2018).

The intensity of tissue growth is caused by the prevalence of assimilation processes in them over dissimilation processes. The technology of beef production is based on biological processes that determine the growth and development of young cattle. From the moment of an organism's emergence to the complete formation of an animal, the number of cells increases, as well as mass and sizes of tissues and organs, their differentiation and specialization (Varga et al., 2016).

When evaluating the growth and development of the experimental livestock population, it has been considered that the animal phenotype is formed under the influence of the genotype and the environment at all stages of ontogenesis. Surely, the growth intensity of bulls and heifers up to 8 months of age was significantly influenced by acclimatization processes, which affected the tension of physiological functions. Some decrease of growth intensity from 8 months of age was caused by stress factors related to weaning of calves from their mothers as well as change of feed factor. By comparing the received data, quite high indicators of growth intensity in bulls are marked, which is obviously caused by more intensive processes of muscular and adipose tissue formation. A decrease in heifers' growth rates in comparison with bulls is attributed to earlier physiological maturity of heifers for further reproduction.

Lifetime estimation of growth intensity in bulls and heifers was studied based on indices of live-weight, average daily growth and relative growth rate of experimental animals. These indices were determined monthly from birth to slaughter in bulls and to becoming a first-calf heifer in heifers. The dynamics of live weight in experimental animals was determined by individual weighing in the morning before feeding. The data obtained were statistically processed by IBM SPSS Statistics 20.0. Software for live weight, average daily gain and relative growth rate.

In close connection with the concept of growth is the concept of meat formation. During the development of young animals, the increase in body mass is mainly due to an increase in the mass of muscle tissue. In this regard, carcass weight is the main indicator of beef productivity, which is formed in well-developed animals with strong bones and excellent muscle tissue.

The main purpose of growing animals of meat breeds is to get maximum live weight and high-quality beef. In the process of animal growth, its physique and chemical composition of tissues undergo significant changes. With increasing body weight there are significant shifts in the ratio between different parts of the body, as well as between fat, muscle, connective and bone tissue (Cheng et al., 2015).

With age, the water content in the animal body decreases, while the fat, protein and minerals increase. The physical and chemical activity of enzyme systems of cells and blood decreases, as well as albumin content, while the serum globulin content increases. In addition, the composition of the muscle cells changes. The content of water in them decreases and the amount of contractile (actin, myosin) or respiratory proteins (myoglobin) increases depending on the type of cultivation. Meat is defined as animal muscle tissue, which consists of transversely striped muscle fibers, connective (collagen and elastic fibers) and adipose tissue (Romanova, 2016; Vestergaard et al., 2019).

The productivity, quality and nutritional advantages of beef depend on many factors, the most important of which are age, intensity of cultivation, breed, sex and animal fatness. In this case, the most important role is attributed to the correspondence of the genotype to the conditions of the external environment. The factors that depend simultaneously on genetic factors and various environmental conditions include growth rate, body shape and size, as well as ratios of individual parts of the animal carcass. The above data are one of the arguments proving the expediency of bull growth extension up to 20 months of age. The carcasses of such animals have a high slaughter yield, both in absolute and relative values and are heavier due to powerfully developed muscles. The higher intensity of body weight gain in Limousine cattle can be explained by their relatively late maturity due to the specifics of the physiological processes flow in their organism.

\section{Conclusion}

One of the reserves to increase the production of high-quality and ecologically pure beef in the conditions of the Russian Federation is the intensive cultivation of Limousine cattle breed, which is justified by the studies of their growth, development and beef productivity.

Breeding Limousine bulls and heifers showed significant differences in growth intensity in different age periods. In the period from birth to 19 months, the live weight of bulls was $619.2 \mathrm{~kg}$ and that of heifers was $459.0 \mathrm{~kg}$. The average daily increase from birth to 19 months in bulls was 928.3 grams and in heifers 476.7 grams.

Studies show that the use of Limousine livestock contributes to a rapid increase in high-quality beef. Heavy carcasses are received from bulls of Limousine breed, as live weight at the entrance on meat processing plant was $674 \mathrm{~kg}$ and total loss of live weight was $6.2 \%$. 
The slaughter yield of 20-monthly bulls was high $63.2 \%$, which is one of the arguments for the need to sell bulls of all breeds for meat at the age of 20 months.

\section{Funding Information}

This research did not receive any specific grant from funding agencies in the public, commercial, or not-forprofit sectors.

\section{Author's Contributions}

All authors contributed equally to the experimentation, read and approved the final manuscript.

\section{Ethics}

The authors declare that the work is written with due consideration of ethical standards.

\section{References}

Abbasov, R. T., \& Abdulaeva, G. G. (2015). Formation of beef productivity of feeder young cattle. Zootechnia. 2 , 8-10. https://elibrary.ru/item.asp?id=23048811

Albertí, P., Panea, B., Sañudo, C., Olleta, J. L., Ripoll, G., Ertbjerg, P., ... \& Hocquette, J. F. (2008). Live weight, body size and carcass characteristics of young bulls of fifteen European breeds. Livestock Science, 114(1), 19-30.

Gorbatov, V. M. (2017). GOST 34120-2017 "Cattle for slaughter. Beef and veal carcasses, semi-carcasses and quarters". All-Russian Scientific Research Institute of the Meat Industry. http://docs.cntd.ru/document/556309575

Ambrosini, D. P., Malhado, C. H. M., Martins Filho, R., Cardoso, F. F., \& Carneiro, P. L. S. (2016). Genotypex environment interactions in reproductive traits of Nellore cattle in northeastern Brazil. Tropical animal health and production, 48(7), 1401-1407.

Avzalov, M. (2016). Development of the livestock farming in the Russian Federation. International Agriculture Journal. 5, 20-23.

Batanov, S. D., \& Starostina, O. S. (2017). Realization of productive and reproductive potential of cattle the forecast of efficient beef production. Reserach Results. 2, 20-26.

Bragaglio, A., Napolitano, F., Pacelli, C., Pirlo, G., Sabia, E., Serrapica, F., ... \& Braghieri, A. (2018). Environmental impacts of Italian beef production: A comparison between different systems. Journal of Cleaner Production, 172, 4033-4043.
Cheng, W., Cheng, J. H., Sun, D. W., \& Pu, H. (2015). Marbling analysis for evaluating meat quality: Methods and techniques. Comprehensive Reviews in Food Science and Food Safety, 14(5), 523-535.

Crichton, S. O., Kirchner, S. M., Porley, V., Retz, S., von Gersdorff, G., Hensel, O., ... \& Sturm, B. (2017). Classification of organic beef freshness using VNIR hyperspectral imaging. Meat science, 129, 20-27.

Cunningham, B. E., \& Klei, L. (1995). Performance and genetic trends in purebred Simmental for regions of the United States. Journal of animal science, 73(9), 2540-2547.

De Vries, M. D., Van Middelaar, C. E., \& De Boer, I. J. M. (2015). Comparing environmental impacts of beef production systems: A review of life cycle assessments. Livestock Science, 178, 279-288.

Dick, M., da Silva, M. A., \& Dewes, H. (2015). Life cycle assessment of beef cattle production in two typical grassland systems of southern Brazil. Journal of Cleaner Production, 96, 426-434.

Gangnat, I. D., Kreuzer, M., Clavijo McCormick, A., Leiber, F., \& Berard, J. (2016). Carcass and meat quality of finished and non-finished Limousin heifers from alpine livestock systems differing in altitudinal origin of the forage. Archives of animal nutrition, 70(2), 108-126.

Lukianov, V. N. (2017). Specifics of beef productivity in bulls of Simmental breed and its crossbreeding with Aberdeen-Angus and Limousine cattle. Glavnyi Zootechnic. 1, 12-20. http://www.old.timacad.ru/catalog/disser/dd/lukyano v/dd_lukyanov.pdf

Nogalski, Z., Sobczuk-Szul, M., PogorzelskaPrzybyłek, P., Wielgosz-Groth, Z., Purwin, C., \& Modzelewska-Kapituła, M. (2016). Comparison of slaughter value for once-calved heifers and heifers of Polish Holstein-Friesianx Limousine crossbreds. Meat science, 117, 1-6.

Phocas, F., \& Laloë, D. (2004). Genetic parameters for birth and weaning traits in French specialized beef cattle breeds. Livestock Production Science, 89(2-3), 121-128.

Romanova, T. (2016). Improving the beef production in Russia. International Agriculture Journal. 1, 34-36. https://cyberleninka.ru/article/n/sovershenstvovanieorganizatsii-proizvodstva-govyadiny-v-rossii

Varga, A., Molnár, Z., Biró, M., Demeter, L., Gellény, K., Miókovics, E., ... \& Babai, D. (2016). Changing year-round habitat use of extensively grazing cattle, sheep and pigs in East-Central Europe between 1940 and 2014: Consequences for conservation and policy. Agriculture, Ecosystems \& Environment, 234, 142-153. 
Irina Vlasova et al. / American Journal of Animal and Veterinary Sciences 2020, 15 (4): 266.274 DOI: 10.3844/ajavsp.2020.266.274

Vestergaard, M., Jørgensen, K. F., Çakmakçı, C., Kargo, M., Therkildsen, M., Munk, A., \& Kristensen, T. (2019). Performance and carcass quality of crossbred beef $x$ Holstein bull and heifer calves in comparison with purebred Holstein bull calves slaughtered at 17 months of age in an organic production system. Livestock Science, 223, 184-192.
Vorobyev, V. I., Vorobyev, D. V., Zakharkina, N. I., Polkovnichenko, A. P., \& Safonov, V. A. (2019). Physiological status of'king'squab pigeon (Columba Livia gm. Cv.E'king') in biogeochemical conditions of low iodine, selenium and cobalt levels in the environment. Asia Life Sciences, 28(1), 99-110. 